\title{
Aberrant Development of Motor Axons and Neuromuscular Synapses in MyoD-Null Mice
}

\author{
Zuo-Zhong Wang, ${ }^{1 *}$ Charles H. Washabaugh, ${ }^{2 *}$ Yun Yao, ${ }^{1}$ Jun-Mei Wang, ${ }^{1}$ Lili Zhang, ${ }^{1}$ Martin P. Ontell, ${ }^{2}$ \\ Simon C. Watkins, ${ }^{2}$ Michael A. Rudnicki, ${ }^{3}$ and Marcia Ontell ${ }^{2}$ \\ Departments of ${ }^{1}$ Neurobiology and ${ }^{2}$ Cell Biology and Physiology, University of Pittsburgh School of Medicine, Pittsburgh, Pennsylvania 15261, and \\ ${ }^{3}$ Department of Molecular Medicine, Ottawa Health Research Unit, Ottawa Hospital, Ontario, Canada K1Y4E9
}

\begin{abstract}
Myogenic regulatory factors (MRFs), muscle-specific transcription factors, are implicated in the activity-dependent regulation of nicotinic acetylcholine receptor (AChR) subunit genes. Here we show, with immunohistochemistry, Western blotting, and electron microscopy that MyoD, a member of the MRF family, also plays a role in fetal synapse formation. In the diaphragm of $14.5 \mathrm{~d}$ gestation (E14.5) wild-type and $\mathrm{MyoD}^{-1-}$ mice, AChR clusters (the formation of which is under a muscle intrinsic program) are confined to a centrally located endplate zone. This distribution persists in wild-type adult muscles. However, beginning at E15.5 and extending to the adult, innervated AChR clusters are distributed all over the diaphragm of $M y o D^{-1-}$ mice, extending as far as the insertion of the diaphragm into the ribs. In wild-type muscle, motor axons terminate on clusters adjacent to the main intramuscular nerve; in $M y o D^{-/-}$muscle, axonal bundles form extensive secondary branches that terminate on the widely distributed clusters. The number of AChR clusters on adult $M y o D^{-1-}$ and wild-type diaphram muscles is similar. Junctional fold density is reduced at $M y o D^{-/-}$endplates, and the transition from the fetal $(\alpha, \beta, \gamma, \delta)$ to adult-type $(\alpha, \beta, \delta, \epsilon)$ AChRs is markedly delayed. However, $M y o D^{-/-}$mice assemble a complex postsynaptic apparatus that includes muscle-specific kinase (MuSK), rapsyn, erbB, and utrophin.
\end{abstract}

Key words: MyoD; knock-out mice; muscle development; neuromuscular junction; nicotinic acetylcholine receptors; MuSK

\section{Introduction}

The myogenic regulatory factors (MRFs) consist of four basic helix-loop-helix (bHLH), muscle-specific transcription factors (MyoD, myf-5, myogenin, and myf-6) that play a critical role in the determination and differentiation of skeletal muscle precursors (Buckingham, 1994; Sabourin and Rudnicki, 2000). These factors form heterodimers with ubiquitous bHLH proteins and bind to a consensus sequence (E box) found in the regulatory regions (promoters or enhancers) of many muscle-specific genes, including those encoding all of the nicotinic acetylcholine receptor (AChR) subunits (Piette et al., 1990; Gilmour et al., 1991; Numberger et al., 1991; Prody and Merlie, 1991; Simon and Burden, 1993). The binding of these heterodimers to the $\mathrm{E}$ boxes results in high levels of transcription.

A few days after the onset of embryonic myotube formation, AChRs become clustered on the myotube membrane. Until recently, AChR subunit gene expression and clustering of the AChRs were thought to require signals derived from the motor neuron, in particular neural agrin (Sanes and Lichtman, 2001; Schaeffer et al., 2001). However, recent studies using mutant mice have demonstrated that the early stages of postsynaptic differentiation are independent of both the motor neuron and neu-

Received 0ct. 21, 2002; revised April 1, 2003; accepted April 3, 2003

This work was supported by National Institutes of Health Grants NS-38301 (Z.Z.W.) and AR-46479 (M.0.) and by grants from the Muscular Dystrophy Association (Z.Z.W., M.O.). We are grateful to Dr. Zach W. Hall (University of California San Francisco) for the MuSK, $\gamma$, and $\epsilon$ subunit antibodies, Dr. Jon Lindstrom (University of Pennsylvania) for the $\beta$ subunit antibody, and the late Dr. John Merlie (Washington University) for the rapsyn antibody.

*Z.Z.W. and C.H.W. contributed equally to this study.

Correspondence should be addressed to Marcia Ontell, Department of Cell Biology and Physiology, University of Pittsburgh School of Medicine, 3550 Terrace Street, Pittsburgh, PA 15261. E-mail montell@pitt.edu.

Copyright $\odot 2003$ Society for Neuroscience $\quad$ 0270-6474/03/235161-09\$15.00/0 ral agrin (Yang et al., 2000, 2001; Lin et al., 2001). A careful examination of embryonic day (E) 14.5 diaphragm muscles of wildtype mice reveals that many of the AChR clusters confined to the center of the muscle are aneural. However, all clusters found at E16.5 in wild-type muscles are innervated (Lin et al., 2001). These studies suggest that (1) a muscle-intrinsic, nerve-, and agrin-independent mechanism initiates the formation of early postsynaptic differentiation at the future endplate zone of the muscle; (2) innervation may refine the initial AChR cluster pre-pattern, with agrin acting to stabilize preexisting clusters or to induce new clusters; and (3) neural signaling molecules are also involved in refining transcription to ensure high levels of AChR transcription in synaptic nuclei, and additional neural signals are probably involved in the elimination of early clusters that remain aneural.

It is established that electrical activity of the muscle fiber gradually represses the synthesis of receptors by nonsynaptic nuclei (Schaeffer et al., 2001). Given that (1) the MRFs bind to E boxes of the AChR subunit genes and that this binding is required for full transcriptional activation of some of these genes and (2) the level of MRF transcripts is regulated by muscle electrical activity, with levels of these transcripts decreasing after developing muscle is innervated (concurrent with the decrease in AChR transcription in nonsynaptic nuclei) and increasing subsequent to denervation (Eftimie et al., 1991; Buonanno et al., 1992; Voytik et al., 1993), concurrent with increases in extrajunctional receptors, it has been proposed that the MRFs play a major role in the pathway by which muscle electrical activity modulates AChR subunit gene expression. The present study tests the hypothesis that one of the MRFs, MyoD (Davis et al., 1987), via one or more of its target genes, also plays a critical role in the establishment of myoneural connections during development. 


\section{Materials and Methods}

Mice. Diaphragm and tibialis anterior muscles were obtained from postnatal day (P) $1,7,14,21,28$, and $42 \mathrm{MyoD}^{-1-}$ (Rudnicki et al., 1992) and $\mathrm{BALB} / \mathrm{c}$ mice. The BALB/c strain was used as the wild-type control, because the $\mathrm{MyoD}^{-1-}$ mice were on a $\mathrm{BALB} / \mathrm{c}$-enriched genetic background (12 back-crosses), and the BALB/c mice used as controls were derived from the same colony used for the back-crosses. Mice were anesthetized (ketamine $0.01 \mathrm{mg} / \mathrm{g}$ body weight and xylazine $0.02 \mathrm{mg} / \mathrm{g}$ body weight, i.p.) and then killed by cervical dislocation. Internal and innermost intercostal muscles (attached to ribs) of P28 mice were also collected. Hindleg muscles of adult mice, denervated by sciaticotomy (Washabaugh et al., 2001), were collected $11 \mathrm{~d}$ after denervation. Diaphragm muscles were also obtained from E14.5, E15.5, and E18.5 fetuses [removed from the uterus of anesthetized null and control dams and staged according to Thieler (1989)] and from P28 heterozygous mice $\left(\mathrm{MyoD}^{+/-}\right)$. The thoracic portion of the phrenic nerves of $\mathrm{P} 42 \mathrm{MyoD}^{-/-}$ and $\mathrm{BALB} / \mathrm{c}$ mice was also collected. The use of animals was in compliance with the guidelines of the Institute Animal Care and Use Committee of the University of Pittsburgh.

Immunocytochemistry. Diaphragm ( $n=4$ for each age group for both types of mice) and intercostal muscles $(n=3$ for both types of mice at $\mathrm{P} 42$ ) were fixed in $2 \%$ paraformaldehyde and incubated with antibodies against neurofilaments (Chemicon, Temecula, CA) and synaptophysin (Dako, Carpinteria, CA). Muscles were incubated with FITC-conjugated goat anti-rabbit IgG (Jackson ImmunoResearch Laboratories, West Grove, PA) and with rhodamine-conjugated $\alpha$-bungarotoxin ( $\alpha$-BuTx) (Molecular Probes, Eugene, OR). Images were collected with an Olympus confocal microscope (Melville, NY). The longest axis of individual AChR clusters was measured using Fluoview software (Lin et al., 2001). Diaphragm muscles ( $n=3$ for both types of mice at P42) were fixed and reacted with anti-rapsyn 5943 (Apel et al., 1995), anti-muscle specific kinase (MuSK) (Fuhrer et al., 1997), anti-erbB2 (SC-284), antineuregulin (SC-348) (Rimer et al., 1998) (Santa Cruz Biotechnology, Santa Cruz, CA), or anti-utrophin (NC L-DRP2) (Grady et al., 2000) (Vector Laboratories, Burlingame, CA), or stained for AChE (Merlie and Sanes, 1985) followed by rhodamine-conjugated $\alpha$-BuTx.

To study the transition from fetal to adult-type AChRs, frozen sections of the tibialis anterior muscles were incubated with an antibody against the $\gamma$-subunit (anti- $\gamma$ 485) or the $\epsilon$-subunit (anti- $\epsilon$ 360) (Gu and Hall, 1988 ) and then reacted with FITC-conjugated goat anti-rabbit IgG and rhodamine-conjugated $\alpha$-BuTx.

Electron microscopy. MyoD ${ }^{-/-}$and BALB/c mice $(n=5$ for each group at P42) were anesthetized with sodium pentobarbital and perfused with buffered $4 \%$ paraformaldehyde and $4 \%$ glutaraldehyde. Diaphragm muscles were dissected, fixed, and stained lightly for AChE (Karnovsky and Roots, 1964). The endplate-rich region of the wild-type muscles and regions of the $\mathrm{MyoD}^{-1-}$ muscle containing multiple endplates were processed for electron microscopy (EM) (Ontell et al., 1988). The first 10 endplates found in each muscle, regardless of size, were photographed. The thoracic portion of phrenic nerves of these mice $(n=3)$ was processed similarly, and $0.5 \mu \mathrm{m}$ sections were stained with toluidine blue.

Western blotting. Detergent extracts of diaphragm and hindlimb muscles $(n=4$ for each age group, for each muscle, for each type of mouse) were separated by SDS-PAGE and transferred to nitrocellulose membranes ( $\mathrm{Gu}$ and Hall, 1988). Membranes were probed with the anti- $\gamma$ 485 , anti- $\epsilon$ 360, anti- $\beta$ (monoclonal antibody 124 ) (Gullick and Lindstrom, 1983), or anti-MuSK, followed by a HRP-conjugated secondary antibodies (Pierce, Rockford, IL) and ECL reagents (Amersham Biosciences, Arlington Heights, IL).

AChE staining and ${ }^{125} I-\alpha-B u T x$ binding assay. Hemi-diaphragm muscles of P42 $\mathrm{MyoD}^{-/-}$and wild-type mice ( $n=4$ for each group) were incubated with $5 \mathrm{~nm}{ }^{125} \mathrm{I}-\alpha$-BuTx $(220 \mathrm{Ci} / \mathrm{mmol}$; Amersham Biosciences) in PBS containing 0.5\% BSA for $2 \mathrm{hr}$, stained for AChE (Merlie and Sanes, 1985), cut into serial, $100-\mu \mathrm{m}$-wide strips (parallel to the intramuscular phrenic nerve), and counted for bound ${ }^{125} \mathrm{I}-\alpha$-BuTx with a gamma counter. The strips were mounted on glass slides, and AChEpositive endplates were counted using a dissecting microscope.

Tissue culture and AChR clustering assay. Primary cultures $(n=3$ for wild-type and $\mathrm{MyoD}^{-1-}$ cultures) were established from hindlimb muscles of newborn mice and maintained in proliferation media for $3 \mathrm{~d}$, as described in Ontell et al. (1992). Cells were then seeded into $10 \mathrm{~mm}$ cloning cylinders (200 cells per square millimeter). After $4 \mathrm{~d}$ in differentiation media, some dishes were treated for $5 \mathrm{hr}$ with recombinant agrin $\mathrm{C}-\mathrm{Ag}_{12,4,8}$ [prepared as in Ferns et al. (1993)]. All dishes were stained with rhodamine-conjugated $\alpha$-BuTx. The number of AChR clusters, $>2.5 \mu \mathrm{m}$ in diameter, and the area of myotube segments were determined for 10-20 random fields for each dish using a fluorescence microscope. The number of AChR clusters was expressed per area of myotube. Data were analyzed using a Student's $t$ test.

\section{Results}

Aberrant axonal branching patterns and AChR cluster distribution in diaphragm muscles of MyoD-null mice Diaphragm muscles of postnatal wild-type (BALB/c) and homozygous $\mathrm{MyoD}^{-/-}$mice (ranging in age from P1 to P42) were reacted with antibodies against neurofilaments and a synaptic vesicle protein, synaptophysin, permitting visualization of patterns of axon outgrowth with a confocal microscope. In wild-type mice, the intramuscular nerve trunk is located in the central region of the muscle, oriented perpendicular to the long axis of the myofibers. Axons leave the nerve and form short branches that terminate at AChR clusters found adjacent to the main nerve, resulting in a narrow, well defined endplate zone in the middle of the muscle (Fig. $1 A-D$ ). In the $M y o D^{-/-}$mice, at all postnatal stages, a main nerve trunk can be discerned only occasionally. When present, it is considerably thinner than that in the diaphragm of wild-type mice (Fig. 1, compare $A, a$ ). In other cases, the phrenic nerve, on entering the muscle, branches immediately into smaller axonal bundles that arborize extensively, some reaching the edge of the diaphragm (Fig. $1 a-d$ ). Thus, patterns of branching and termination of intramuscular axons are aberrant in homozygous $\mathrm{MyoD}^{-1-}$ mutants.

Diaphragm muscles labeled with antibodies to neurofilaments and synaptophysin were also labeled with rhodamineconjugated $\alpha$-BuTx. In wild-type mice, all AChR clusters are located in the distinct "endplate zone" in the central third of the diaphragm (Fig. $1 A^{\prime}-D^{\prime}$ ). Presynaptic nerve terminals precisely overlie individual AChR clusters. In $\mathrm{MyoD}^{-/-}$mice, at all postnatal stages, AChR clusters are scattered over the entire surface of diaphragm (Fig. 1 $a^{\prime}-d^{\prime}$ ) with clusters extending to the edge of the muscle. Although the AChR clusters are widely dispersed across the muscle, the spatial relationship between presynaptic and postsynaptic structures is maintained in the mutant (Fig. 2, compare $C, c, c^{\prime}$ ). In $M y o D^{+/-}$(heterozygote) mice, neuronal branching and the location of the AChR clusters are similar to that found in wild-type muscles (Fig. $2 A$ ).

Two techniques were used to determine the distribution of clusters and the number of endplates on the hemi-diaphragms of P42 $\mathrm{MyoD}^{-/-}$and BALB/C mice [counting of the amount of bound ${ }^{125} \mathrm{I}-\alpha$-BuTx (in a gamma counter) and determination of the number of AChE-positive regions (AChE having been shown to localize adjacent to AChR clusters in both types of muscle; data not shown) present in serial sections cut parallel to the intramuscular phrenic nerve, as described in Materials and Methods ]. The toxin-binding activity and number of AChE-positive endplates on individual strips were each plotted against the distance of the strip from the main intramuscular nerve trunk. Using either technique, most $(>98 \%)$ of the neuromuscular junctions in wild-type mice are found in a narrow zone $(\sim 2 \mathrm{~mm}$ wide) in the middle of the diaphragm, whereas in $\mathrm{MyoD}^{-/-}$mice, less than one-third of the junctions are found in the $\sim 2$-mm-wide zone around the nerve trunk, with the remaining junctions being 


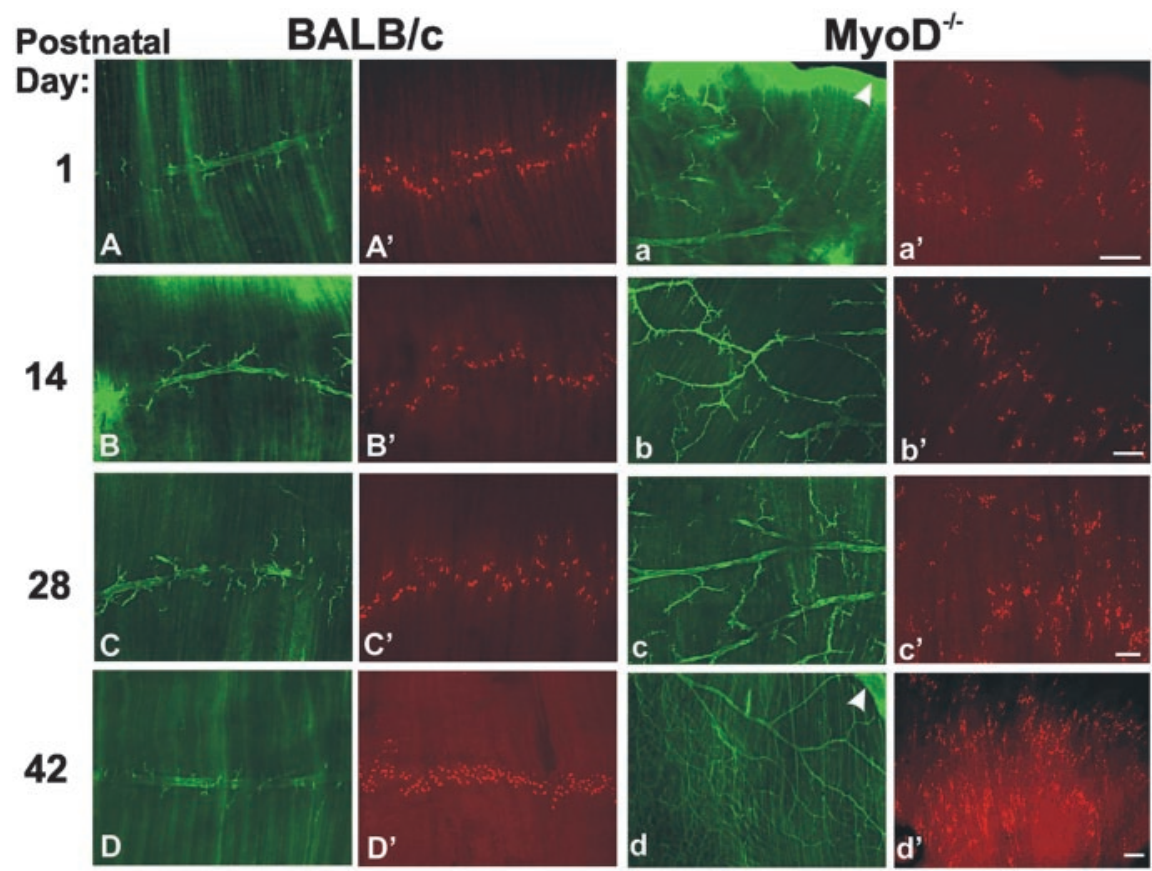

Embryonic
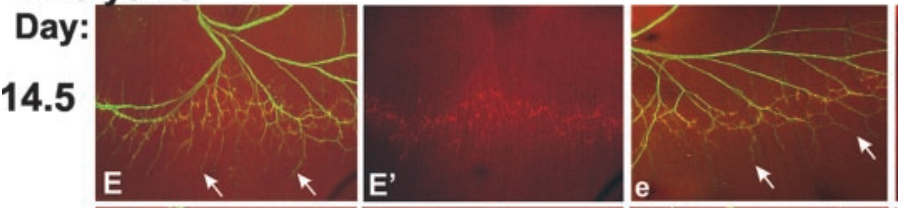

15.5
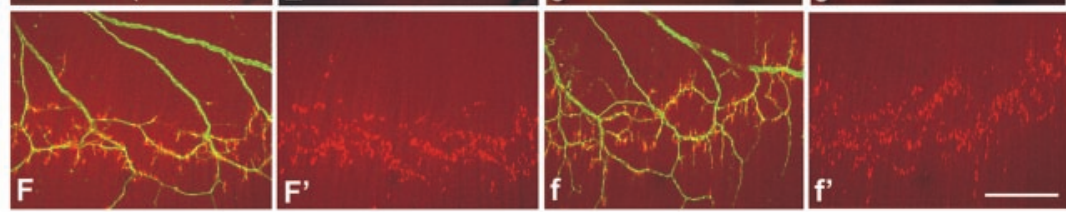

Figure 1. Development of abnormal cluster distribution and axonal branching in $M y 0 D^{-/-}$mice. Confocal images of motor axons and $A C h R$ clusters in diaphragm muscles from $B A L B / C$ and $M y O D^{-1-}$ mice at $P 1,14,28$, and 42 (top panels), and E14.5 and E15.5 (bottom panels). Muscles were reacted with a mixture of antibodies against neurofilament and synaptophysin and with an FITC-conjugated secondary antibody to label preterminal and terminal portions of the motor axons $(A-F, a-f)$ and with rhodamine-conjugated $\alpha$-BuTx to label AChRs $\left(A^{\prime}-F^{\prime}, a^{\prime}-f^{\prime}\right)$. In the BALB/cdiaphragms, at all postnatal ages, neuronal branches $(A-D)$ and $A C h R$ clusters $\left(A^{\prime}-D^{\prime}\right)$ are confined to the middle of the muscle (in a discrete endplate band), whereas in the diaphragms of $M y O D^{-1-}$ mice, there is extensive ramification of neuronal branches $(a-d)$ throughout the muscle, extending to the edge of the diaphragm ( $a, d$, arrowheads). AChR clusters are distributed throughout the muscle, corresponding to the distribution of the axon terminals $\left(a^{\prime}-d^{\prime}\right)$. At E14.5 a discrete band of AChR clusters is found in the middle of the diaphragms of both BALB/C $\left(E^{\prime}\right)$ and $M y O D^{-1-}$ mice $\left(e^{\prime}\right)$. The FITC and rhodamine images were overlapped $(E, F, e, f)$, showing that some terminal axons are not apposed to AChR clusters at E14.5 ( $E$, e, arrows.). ByE15.5 motor axons have grown out of the central zone of the muscle fibers, and new AChR clusters are formed at the axon terminals of the $M y 0 D^{-1-}$ mice $(f)$, resulting in a wider, more diffuse endplate band $\left(f^{\prime}\right)$ than is found in age-matched BALB/c muscle $\left(F^{\prime}\right)$. Scale bars, $100 \mu \mathrm{m}$. For each age group, micrographs are at the same magnification.

spread over the entire surface of the muscle. The total number of neuromuscular junctions and ACh-binding sites in a hemidiaphragm muscle from $M y o D^{-/-}$mice (2017 endplates, 6.20 pmol ${ }^{125} \mathrm{I}-\alpha$-BuTx bound) were similar to those in the BALB/c mice (1973 endplates, $6.06 \mathrm{pmol}{ }^{125} \mathrm{I}-\alpha$-BuTx bound).

\section{Initially AChR clusters are confined to the middle of the} diaphragm of $\mathrm{MyoD}^{-/-}$mice

At E14.5, in both wild-type and $M y o D^{-/-}$mice, intramuscular nerves run through the central region of the diaphragm and branch into bundles that grow toward the anterior or posterior edges of the muscle. Short axon branches emanate from the nerve bundles and end in the central third of the diaphragm (Fig. 1E,e).

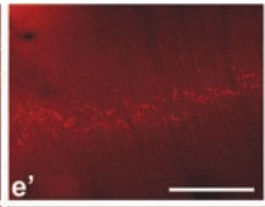

A very faint band of AChR clusters is present in the middle of the diaphragm muscles of both control and mutant mice (Fig. $1 E^{\prime}, e^{\prime}$ ). With the confocal microscope, $\sim 75 \%$ of the AChR clusters on both types of muscle were found to be aneural (Table 1). Moreover, a significant number of the terminal endings of the axons in both types of mice are not associated with AChR clusters (Fig. $1 E, e$ ). At E15.5, the terminal endings in the wild-type muscle remain confined to the endplate zone (Fig. $1 F$ ). In contrast, motor axons in the E15.5 $\mathrm{MyoD}^{-/-}$diaphragm begin to spread out of the endplate zone, and new AChR clusters are induced to form at the terminal endings of the axons (Fig. $1 f, f^{\prime}$ ). At E15.5, in both types of diaphragm muscles, $>90 \%$ of the AChR clusters are innervated (Table 1). Taken together, these results demonstrate that (1) the earliest AChR clusters formed in the diaphragm of the $\mathrm{MyoD}^{-/-}$mice (clusters that form without neural induction) are located at the appropriate region (i.e., the middle of the muscle); (2) the time course of innervation of the AChR clusters is similar in the $M y o D^{-/-}$and $\mathrm{BALB} / \mathrm{c}$ diaphragms; and (3) an aberrant distribution of AChR clusters and an aberrant pattern of motor axonal branching begin shortly after innervation and persist into adulthood in $\mathrm{MyoD}^{-/-}$muscles.

\section{Polyneuronal elimination follows the same time course in $\mathrm{MyoD}^{-/-}$and BALB/c mice}

Postnatal polyneuronal innervation elimination (hereafter termed synapse elimination) was evaluated by counting the number of motor axons that entered each AChR-rich endplate using the confocal microscope. For each age group, a total number of 150 endplates, from three $\mathrm{BALB} / \mathrm{c}$ and three $\mathrm{MyoD}^{-/-}$mice, were examined. At $\mathrm{P} 1$, in both types of mice, myelinization of the intermuscular branches of the phrenic nerve had just begun, with only a few axons displaying a single layer of myelin. At this stage, 61 and $63 \%$ of the muscle fibers are singly innervated in wild-type and mutant diaphragms, respectively. By $\mathrm{P} 7,90 \%$ of the endplates in a wild-type muscle and $89 \%$ of endplates in mutant muscle are singly innervated. All endplates, in both types of muscle, are singly innervated by P14. Thus, the time course of synapse elimination is similar in $\mathrm{MyoD}^{-1-}$ and wild-type muscles.

\section{Abnormalities in innervation are not confined to the diaphragm muscle of $M y o D^{-/-}$mice}

To determine whether the defects described above are restricted to diaphragm muscles, we stained AChRs in whole mounts of intercostal muscles of P28 mice. The central zone of AChR clusters in the intercostal muscles from P28 $\mathrm{MyoD}^{-/-}$mice is considerably wider than that from BALB/c mice (Fig. $2 B$ ). Similarly, a more diffuse distribution of AChR clusters is found in the ster- 

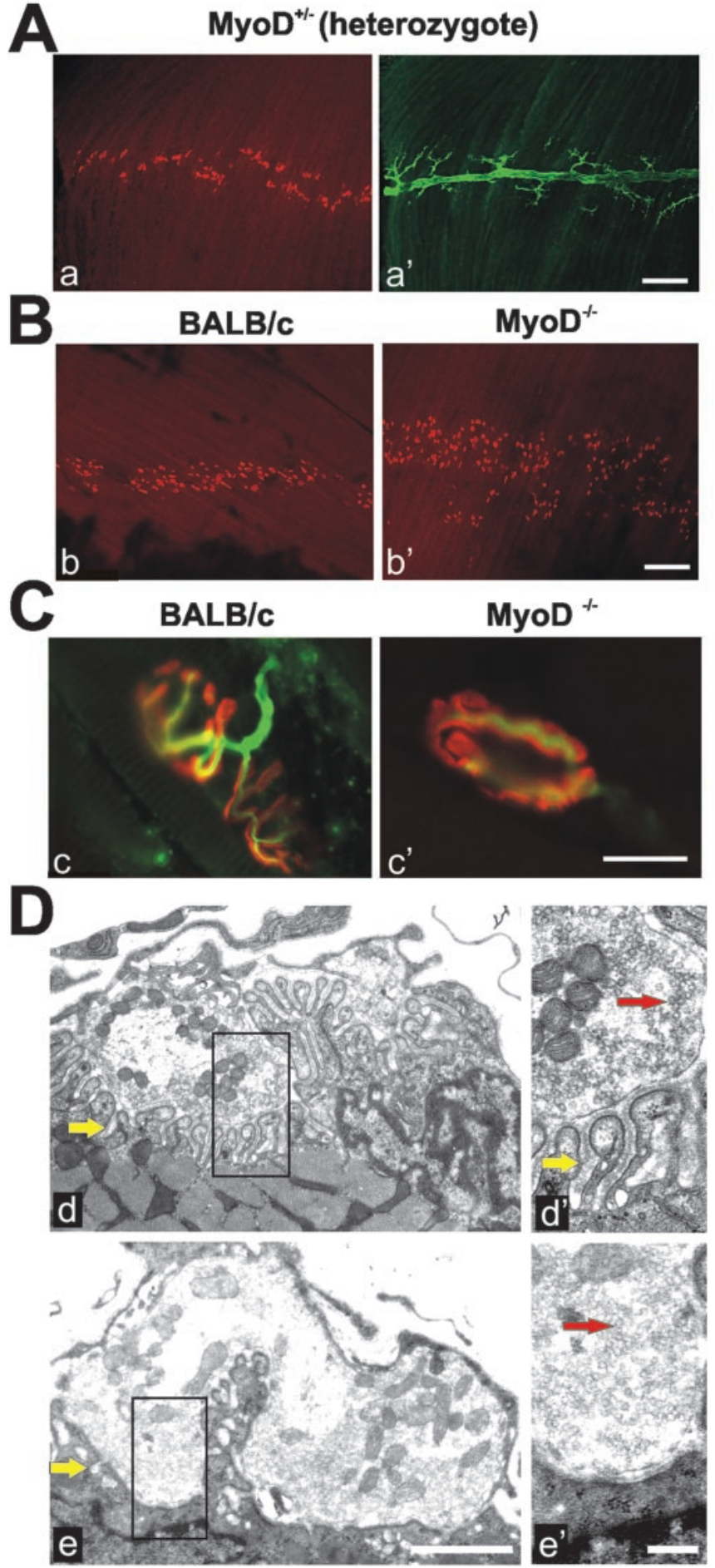

Figure 2. Confocal and electron microscope images of nerve terminals and endplates demonstrating abnormalities in the $\mathrm{MyOD}^{-/-}$mouse. A, Diaphragm muscles of P28 MyoD $\mathrm{D}^{+/-}$ (heterozygote) mice display an AChR cluster distribution (after reaction with rhodaminelabeled $\alpha$-BuTx) ( $a$ ) and nerve branching (after immunostaining with a mixture of antibodies against neurofilament and synaptophysin and an FITC-conjugated secondary antibody) $\left(a^{\prime}\right)$ similar to that in wild-type muscles. Scale bar, $200 \mu \mathrm{m}$. B, Intercostal muscles of P28, BALB/C $(b)$, and $\mathrm{MyOD}^{-1-}\left(b^{\prime}\right)$ mice reacted with rhodamine-conjugated $\alpha$-BuTx. The endplate zone in the $\mathrm{MyOD}^{-/-}$intercostal muscle is wider than in the BALB/c muscle. Scale bar, $200 \mu \mathrm{m} . \mathrm{C}$, Diaphragm muscles of $\mathrm{P} 42 \mathrm{BALB} / \mathrm{C}(\mathrm{c})$ and $\mathrm{MyOD}^{-1-}\left(c^{\prime}\right)$ mice reacted with antibodies against neurofilament and synaptophysin and an FITC-conjugated second antibody and rhodamineconjugated $\alpha$-BuTx. Terminal branches of the axons overlie postsynaptic AChR clusters in both muscles. The branching of the terminal axons is less complex, and the "pretzel-like" appearance of the wild-type AChR clusters is not present in the $M y 0 D^{-1-}$ mice. Scale bar, $20 \mu \mathrm{m} . D$, nomastoid muscles of adult $\mathrm{MyoD}^{-/-}$as compared with wildtype mice (data not shown).

\section{Postsynaptic morphology is altered in MyoD-null mice}

On wild-type muscles of P42 mice, a single axon contacts each muscle fiber and branches and terminates on the surface of the muscle fiber in a circumscribed spray of varicose branches. AChR clusters display a pretzel-like pattern with sharp boundaries. Presynaptic and postsynaptic structures are completely apposed (Fig. $2 C, c$ ). In contrast, endplates in age-matched $\mathrm{MyoD}^{-/-}$mice are poorly differentiated. Nerve terminals have fewer branches. Nerve terminals and AChR clusters are apposed, but AChR clusters are oval shaped with blurred boundaries (Fig. $2 C, c^{\prime}$ ). The lengths of AChR clusters (major diameter) in wild-type mice and in $\mathrm{MyoD}^{-1-}$ muscle are $59 \pm 4.8$ and $51 \pm 4.2 \mu \mathrm{m}$, respectively (mean \pm SEM; $n=100$ clusters from three control and mutant mice).

Endplates of P42 mice were examined with an electron microscope. In both types of mice (Fig. $2 D$ ), nerve terminals are packed with synaptic vesicles. Schwann cells extend thin processes that cap the nerve endings, and basal lamina is present in the synaptic cleft. Thus, gross presynaptic differentiation has taken place in the mutant mice. The postsynaptic membrane is invaginated into numerous, $\sim 1-\mu \mathrm{m}$-deep folds in adult wild-type muscles (Fig. $\left.2 D, d, d^{\prime}\right)$. In adult $M y o D^{-1-}$ muscle, the number of junctional folds is reduced, and the residual membrane folds are shallow and less complex. More than 40 neuromuscular synapses in $\mathrm{MyoD}^{-/-}$ mice, some from the center of the muscle and others that were widely dispersed over the diaphragm, were examined. No significant differences in the morphological appearance of the endplates, on the basis of their location in the diaphragm, were observed. In the synapses of $\mathrm{MyoD}^{-/-}$mice, junctional folds are rarely found that are as well developed as those in controls (i.e., the most highly developed synaptic folds seen at wild-type endplates are not found in the $M y o D^{-/-}$mice). The frequency of finding axon terminals in the $M y o D^{-/-}$muscle that sit in a primary synaptic cleft, with few, if any, subsynaptic folds (Fig. $\left.2 D, e, e^{\prime}\right)$, is greater in null muscles than in wild-type muscles. The changes in the postsynaptic morphology in $\mathrm{MyoD}^{-/-}$mice were similar whether the endplates were located in the central region of the diaphragm or outside the usual endplate zone.

To determine whether the change in the morphology of the postsynaptic region was caused by morphological deficits in the phrenic nerve, toluidine blue-stained sections of the phrenic nerves of both types of mice ( $n=3$, at P42) were examined. There was no significant difference in the number of myelinated axons in the phrenic nerves of $\mathrm{MyoD}^{-/-}(296 \pm 20$ axons) (mean \pm $\mathrm{SEM})$ versus BALB/c (269 \pm 9.6$)$ mice. Moreover, the thickness of the myelin sheaths was indistinguishable in the null versus wild-type phrenic nerves (data not shown). Although both myelinated motor and sensory axons are found in the nerve, a reduction of motor axons in the $M y o D^{-/-}$phrenic nerve should have been reflected in a reduction in the total number of myelinated axons in that nerve. This did not occur.

Electron micrographs of endplates in diaphragms from $\mathrm{P} 42 \mathrm{BALB} / \mathrm{c}\left(d, d^{\prime}\right)$ and $M y \mathrm{D}^{-/-}$mice $\left(e, e^{\prime}\right)$. Yellow arrows indicate subsynaptic folds; red arrows indicate presynaptic vesicles. Boxed regions ind and $e$ are enlarged in $d^{\prime}$ and $e^{\prime}$, respectively. Endplates with complex, well differentiated synaptic folds are found in the control mice $\left(d, d^{\prime}\right)$. Junctional folds at endplates of $M y \mathrm{O}^{-/-}$muscles are generally shallower and less complex (fewer synaptic folds). Occasionally, junctional folds are almost absent in regions adjacent to axon terminals $\left(e^{\prime}\right)$. Scale bars, $1 \mu \mathrm{m}$. 
Table 1. Analysis of AChR clusters in diaphragm muscles of $B A L B / C$ and $M y O D^{-/-}$fetuses

\begin{tabular}{|c|c|c|c|c|c|c|}
\hline & \multicolumn{3}{|l|}{ E14.5 } & \multicolumn{3}{|l|}{ E15.5 } \\
\hline & Innervated clusters (\%) & Uninnervated clusters (\%) & Endplate zone width ( $\mu \mathrm{m})$ & Innervated clusters (\%) & Uninnervated clusters (\%) & Endplate zone width $(\mu \mathrm{m})$ \\
\hline $\mathrm{BALB} / \mathrm{C}$ & 25.4 & 74.6 & $53 \pm 3$ & 92.5 & 7.5 & $81 \pm 4$ \\
\hline$M_{y o D^{-1-}}$ & 24.8 & 75.2 & $60 \pm 4$ & 93.1 & 6.9 & $109 \pm 7^{*}$ \\
\hline
\end{tabular}

The presence or absence of innervation of AChR clusters on diaphragm muscle was evaluated with confocal microscopy of muscles reacted with $\alpha$-BuTx and antibodies to synaptophysin/neurofilaments (300 clusters; $n=4$ muscles for each group at each developmental stage). The width of endplate zone containing AChR clusters represents the mean \pm SEM from six animals.

${ }^{*} p<0.05 ; M y O D^{-1-}$ significantly different from BALB/c controls.

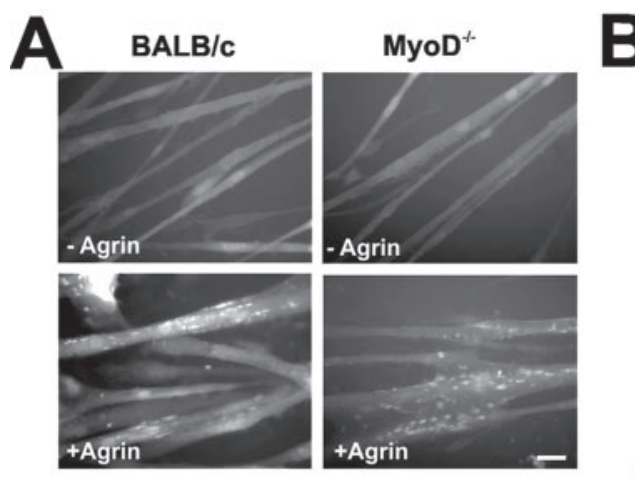

C

E15 E18 P1 P7 P14 Den

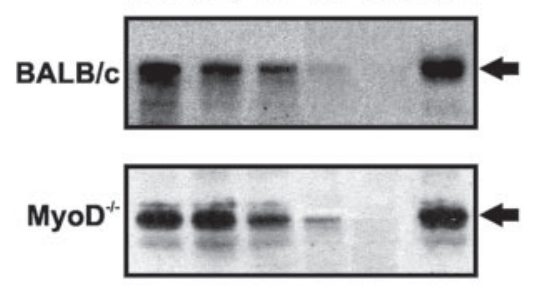

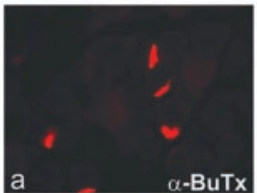
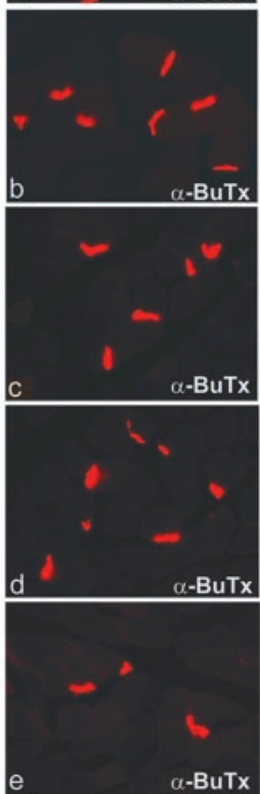

Figure 3. The agrin-MuSK-rapsyn pathway is functional in $M y o D^{-/-}$muscle, and $M y o D^{-/-}$mice assemble a complex postsynaptic apparatus. $A$, MyoD-deficient myotubes form AChR clusters when exposed to neural agrin. Primary cultures of myoblasts derived from leg muscles of newborn $\mathrm{BALB} / \mathrm{cor} \mathrm{MyOD}^{-/-}$mice were allowed to differentiate into myotubes. Myotubes in both types of cultures displayed few AChR clusters in the absence of agrin, whereas both types of cultures, when treated with 10 nм recombinant neural agrin, displayed numerous AChR clusters. Scale bar, $10 \mu \mathrm{m}$. $B$, Confocal images of cross-sections of the diaphragm of P42 MyoD ${ }^{-1-}$ mice reacted with rhodamine-labeled $\alpha$-BuTx $(a-e)$ and with an antibody to MuSK $\left(a^{\prime}\right)$ rapsyn $\left(b^{\prime}\right)$, neuregulin $\left(c^{\prime}\right)$, erbB $\left(d^{\prime}\right)$, or utrophin $\left(e^{\prime}\right)$, followed by an FITC-conjugated secondary antibody. All of these proteins colocalize with the $A C h R$ clusters at the neuromuscular junctions of the diaphragm of $M y O D^{-/-}$mice, as they do in wild-type mice (data not shown). Scale bar, $50 \mu \mathrm{m}$. C, Lysates from leg muscles of E15-P14 MyoD ${ }^{-1-}$ and BALB/C mice were subjected to SDS-PAGE and immunoblotted with an antibody to MuSK and an HRP-labeled secondary antibody. Lysates from denervated (11 $\mathrm{d}$ after denervation) hindlimb muscles served as standard for MuSK (arrow) identification. There were no marked deficits in MuSK levels in $\mathrm{MyOD}^{-1-}$ muscles at any stage studied. Both types of muscle demonstrated an age-related decrease in MuSK during the perinatal period, and both were able to upregulate MuSK in response to denervation.

\section{AChRs are able to cluster on cultured $\mathrm{MyoD}^{-/-}$myotubes} stimulated with agrin

Primary myoblasts derived from the hindlimb muscles of $\mathrm{MyoD}^{-/-}$and BALB/c newborns were allowed to differentiate in vitro to form myotubes. Mutant and wild-type myotubes form a few spontaneous AChR aggregates in the absence of exogenous agrin, whereas large numbers of AChR clusters are induced in both types of cultures after exposure to $10 \mathrm{nM}$ agrin for $5 \mathrm{hr}$ (Fig. $3 A$ ). After exposure to agrin, the number of clusters per square millimeter (mean $\pm \mathrm{SEM}$ ) increased fivefold in BALB/c myotubes (from $384 \pm 87$ to $1902 \pm 121$ ) and 4.8-fold in $\mathrm{MyoD}^{-/-}$ myotubes (from $402 \pm 98$ to $1816 \pm 79$ ). Differences observed be-
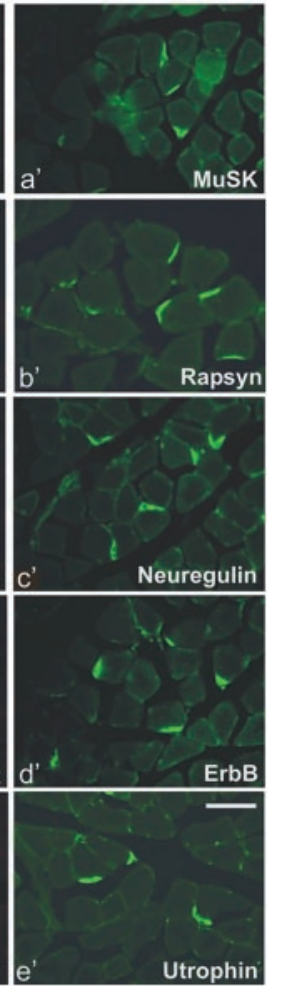

tween control and mutant cultures were not significant $(p>0.05 ; n=3)$.

\section{Muscle fibers in $\mathrm{MyoD}^{-/-}$mice assemble a complex postsynaptic apparatus}

Immunostained whole mounts of the diaphragm viewed with the confocal microscope reveal that rapsyn, MuSK, neuregulin, erbB, and utrophin colocalize with AChRs in muscles of $M y o D^{-/-}$mice (Fig. $3 B$ ) as they do in BALB/c mice (data not shown), and the AChE distribution corresponds to that of AChR clusters in both types of muscle (data not shown).

Because it had been reported that MuSK mRNA was decreased in proliferating myoblasts and "upregulated" more slowly in differentiating $M y o D^{-/-}$myotubes in vitro (Sabourin et al., 1999), MuSK protein in $M y o D^{-/-}$and $\mathrm{BALB} / \mathrm{c}$ limb muscles (from mice E15-P14) and in denervated adult limb muscles was evaluated using Western blotting (Fig. 3C). There is no deficit in the levels of MuSK in the null mutant at any developmental stage. Both types of muscle demonstrate an age-related decrease in MuSK during the perinatal period and a marked increase in MuSK in response to denervation.

\section{Delayed transition from the fetal to adult-type AChRs in muscles of MyoD $^{-/-}$mice}

The effect of the absence of MyoD on the transition from the fetal to the adult-type AChR was evaluated using Western blotting and immunostaining for the $\gamma$ - and $\epsilon$-subunits of the AChRs. For BALB/c diaphragms analyzed with Western blotting, the $\gamma$-subunit protein is at high levels at P1 and decreases significantly by P7; it is undetectable at P14. The $\epsilon$-subunit is not detectable until P7 (Fig. 4). In $M y o D^{-/-}$mice, however, $\gamma$-subunit expression remains high at $\mathrm{P} 14$ and is absent by P21. In these mice, substantial amounts of the $\epsilon$-subunit are first detected at P21 (Fig. 4). These changes in subunit expression are specific for the $\gamma$ - and $\epsilon$-subunits, because at any given stage wild-type and $\mathrm{MyoD}^{-/-}$muscles contain similar amounts of the $\beta$-subunit (Fig. 4).

To determine whether the delay in the emergence of the adult receptor was unique to the diaphragm or would occur in other muscles, cryosections of the tibialis anterior muscles of P1-P42 mice were reacted with the antibodies to the $\gamma$ - or the $\epsilon$-subunit and with 
BALB/C

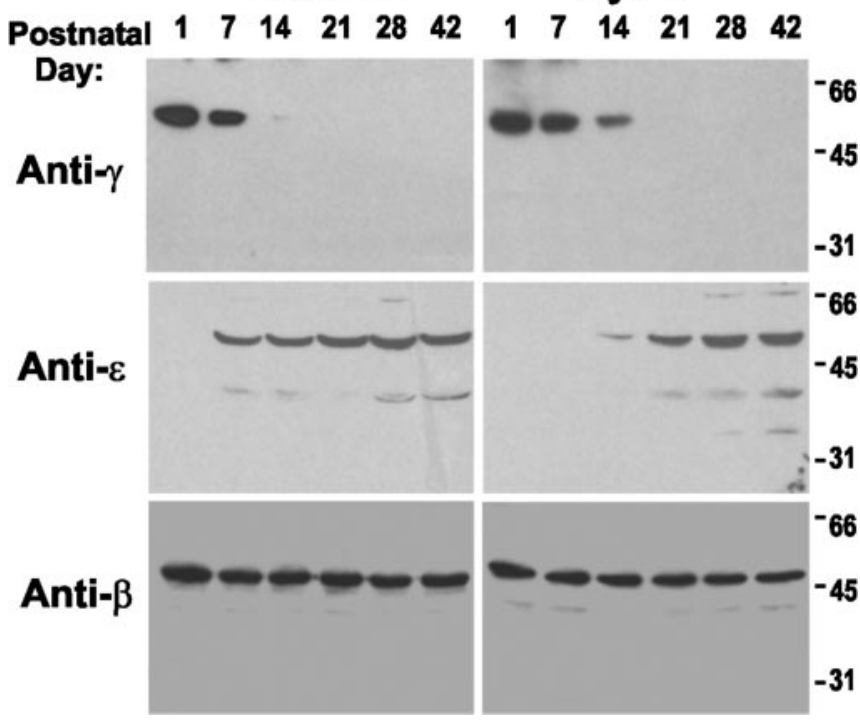

Figure 4. Developmental transition from fetal to adult-type AChRs is delayed in the diaphragm of $\mathrm{MyOD}^{-/-}$mice. Partially purified AChR lysates from the diaphragms of P1-P42 mice were subjected to SDS-PAGE and immunobloted with antibodies specific for the $\gamma_{-}, \epsilon-$, or $\beta$-subunit and HRP-labeled secondary antibodies. Elimination of the $\gamma$-subunit protein is delayed by 1 week in $\mathrm{MyOD}^{-1-}$ as compared with BALB/c mice. The appearance of the $\epsilon$-subunit was also delayed by 1 week in $\mathrm{MyOD}^{-1-}$ mice and did not reach control levels for an additional week. Changes in $\gamma$ - and $\epsilon$-subunit expression were specific, because at any given stage wildtype and $\mathrm{MyOD}^{-/-}$muscles expressed similar amounts of the $\beta$-subunit. Standards on the right are in kilodaltons.

rhodamine-conjugated $\alpha$-BuTx (Figs. 5, 6). In BALB/c muscles, anti- $\gamma$ (Fig. $\left.5 A^{\prime}-E^{\prime}\right)$ strongly stains endplates on muscles of $\mathrm{P} 1$ animals, weakly stains endplates from P7 muscles, and does not detectably stain endplates from P14 or older mice. The $\epsilon$-subunit can be easily detected beginning at $\mathrm{P} 7 \mathrm{in} \mathrm{BALB} / \mathrm{c}$ muscles (Fig. $6 A^{\prime}-E^{\prime}$ ). In contrast, in the $M y o D^{-/-}$muscles, the $\gamma$ antibody (Fig. $5 a^{\prime}-e^{\prime}$ ) strongly stains endplates from as late as P14 mice and weakly stains endplates from P21 muscles, whereas the $\epsilon$-subunit is not detected until P21 (Fig. $6 a^{\prime}-e^{\prime}$ ). Thus, the replacement of the $\gamma$ - by the $\epsilon$-subunits in AChR of $M y o D^{-1-}$ mice is delayed.

\section{Discussion}

The $M y o D^{-/-}$mice were originally described as viable and fertile, with no muscle morphological abnormalities; however, null mice were somewhat smaller than wild-type mice. Although myf-5 mRNA was increased 3.5-fold, levels of many muscle-specific mRNAs were similar to those in wild-type muscle (Rudnicki et al., 1992). Later studies suggested that myogenic cells isolated from MyoD-null mice displayed a reduced differentiation potential (Sabourin et al., 1999) and an altered morphology and failed to express M-cadherin (Sabourin et al., 1999; Cornelison et al., 2000). Moreover, $M y o D^{-1-}$ muscles demonstrated an impaired ability to regenerate (Megeney et al., 1996; White et al., 2000). Although a reduction of myosin heavy chain IIB (MHCIIB) has been reported in the diaphragm of the $\mathrm{MyoD}^{-/-}$mouse, this isoform is overexpressed in other muscles, suggesting that MyoD plays a role in the $\mathrm{MHC}$ profile in a muscle-specific manner (Seward et al., 2001).

There are no previous studies evaluating the effect of the absence of MyoD on muscle innervation. In the present study, we observed that (1) in both wild-type and $\mathrm{MyoD}^{-1-}$ muscles at E14.5 [when many of the AChR clusters found in the diaphragm are not innervated (Lin et al., 2001; the present study)], AChR clusters are confined to the central third of the diaphragm. However, beginning at E15.5 (when more clusters are innervated), the region containing the clusters in the $M y o D^{-/-}$diaphragm is somewhat wider. At all subsequent ages, AChR clusters in $M y o D^{-1-}$ muscle are distributed over the surface of the diaphragm. This suggests that the remodeling of the endplate band by the phrenic nerve is aberrant in the absence of MyoD. (2) In the $M y o D^{-1-}$ mice, axonal bundles fail to stop at the center of diaphragm. Rather, they arborize and run considerable distances throughout the muscle, before termination adjacent to AChR clusters. (3) The density and depth of junctional folds on endplates of MyoD-null muscles are reduced, and (4) the transition from the fetal to the adult-type AChRs is markedly delayed in the mutant. These findings demonstrate that MyoD plays an important role in mechanisms involved in muscle innervation and synaptic differentiation during development.

\section{MyoD and the control of motor innervation of skeletal muscle}

Given that MyoD is expressed only in myofibers, the aberrant neural branching in the $M y o D^{-/-}$mice must reflect impaired retrograde signaling from the MyoD-deficient muscles to either the in-growing motor axons or their Schwann cells. However, preliminary studies in our laboratory suggest that Schwann cells are probably not the primary target of the retrograde signal. Evaluation of the levels of Schwann cell marker mRNAs in the wildtype and MyoD-deficient diaphragm at E16 (when innervation is being established) indicates no significant differences in the levels of these markers. Therefore, it is unlikely that Schwann cells in the null mice are reduced or nonfunctional during development. Moreover, the time course of myelinization of the intramuscular phrenic nerve is similar in the wild-type and null mice.

We suggest that the aberrant neural branching in the $\mathrm{MyoD}^{-/-}$mouse is more likely to reflect an impaired retrograde signal to the in-growing motor axons. Target gene(s), perhaps encoding an adhesion factor(s), may be preferentially activated by MyoD (as opposed to other MRFs), particularly because preliminary studies of the diaphragm muscles of newborn $m y f-5^{-/-}$ mice (a gift from S. Tajbakhsh and M. Buckingham, Pasteur Institute, Paris, France) revealed that they maintain a discrete endplate band (M. Ontell, unpublished observations). Preferential activation of some muscle-specific genes by MyoD has been reported previously in vitro (Brennan et al., 1990; Rosenthal et al., 1990; Allen et al., 2001).

Several muscle-derived adhesion molecules are enriched at endplates of wild-type mice, where they may provide retrograde signals that confine axonal growth and induce nerve endings to differentiate. Muscle agrin and s-laminin, concentrated in junctional basal lamina, act as "stop signals" that inhibit neurite outgrowth in culture (Campagna et al., 1995; Gautam et al., 1996). Other muscle-derived proteins that influence axonal growth in vitro include the neural cell adhesion molecule (N-CAM), tenasin-C, and fibroblast growth factor-5 (FGF-5) (Landmesser, 1996). Although mutant mice deficient for N-CAM, tenasin-C, or FGF-5 fail to reveal major defects in muscle innervation (Moscoso et al., 1998), the pattern of innervation and axonal growth in denervated-reinnervated muscles of tenasin- $C^{-/-}$mice are altered (Cifuentes-Diaz et al., 2002). The absence of MyoD may alter the expression of a combined set of these adhesive molecules. Alternately, M-cadherin, reportedly enriched at normal neuromuscular synapses (Cifuentes-Diaz et al., 1996; Kaufmann et al., 1999) and known to be drastically reduced in myoblast cultures derived from $M y o D^{-/-}$mice (Sabourin et al., 1999), 


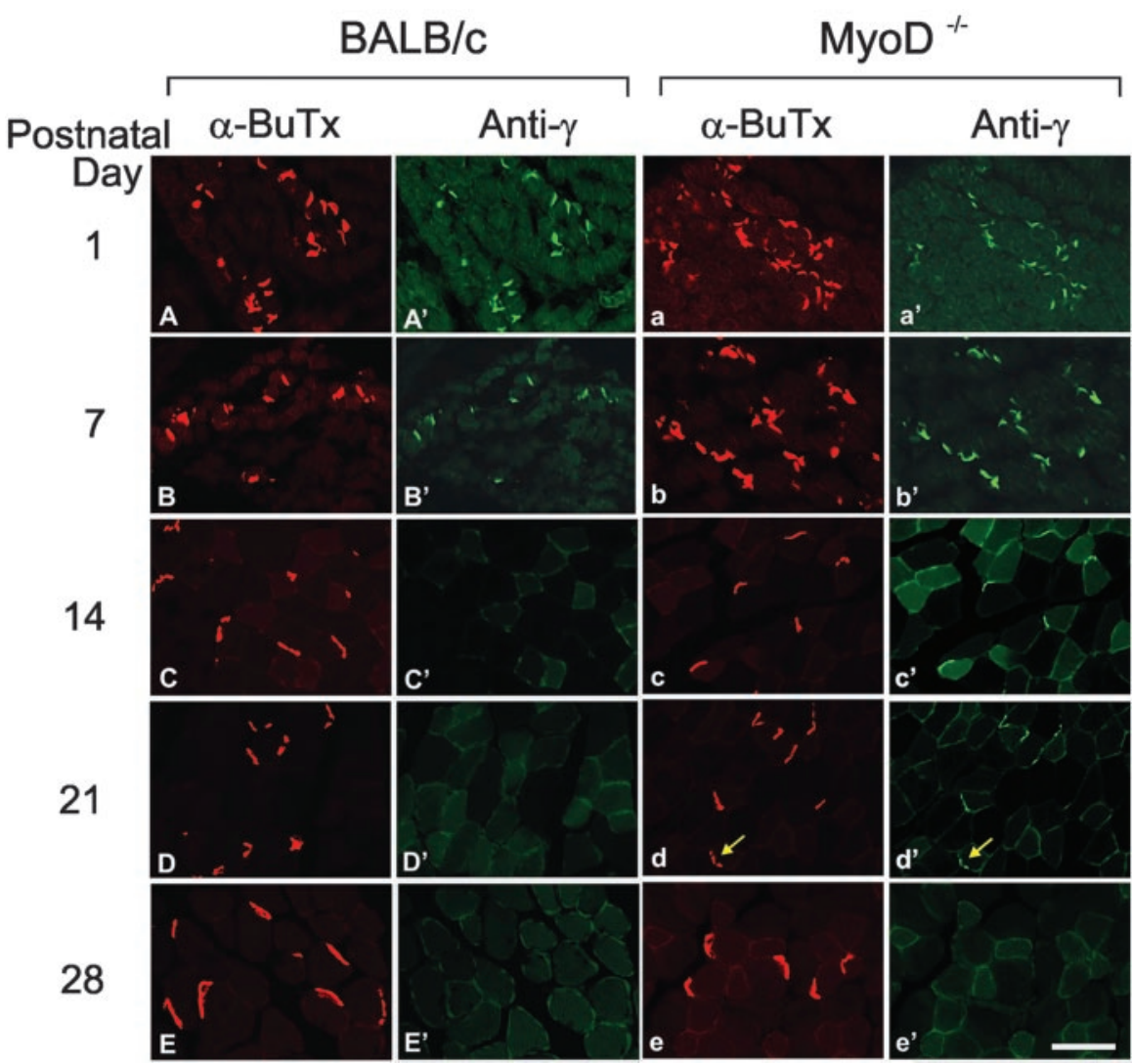

Figure 5. Prolonged expression of the $A C h R \gamma$-subunit in leg muscles of the $M y O D^{-1-}$ mice. Confocal images of sections of the tibialis anterior muscle, taken from P1-P28 BALB/c and $M y 0 D^{-1-}$ mice, that were incubated with an antibody to the $\gamma$-subunit, FITC-conjugated secondary antibody, and rhodamine-labeled $\alpha$-BuTx. The $\gamma$-subunit immunoreactivity diminished after P7 in $\mathrm{BALB} / \mathrm{c}$ muscle, whereas it persisted at $\mathrm{P} 21$ in $\mathrm{MyOD}^{-/-}$mice, as can be seen by the colocalization of weak immunostaining of the $\gamma$-subunit ( $d^{\prime}$, arrow) with $\alpha$-BuTx (d, arrow). Scale bar, $50 \mu \mathrm{m}$.

might seem to be a suitable candidate for the protein providing the retrograde signal. However, preliminary studies in our laboratory (Ontell, unpublished observations) found no significant difference in the levels of mRNA for M-cadherin in $\mathrm{MyoD}^{-/-}$and wild-type mouse diaphragms at E16, just before the time when all of the AChRs in the normal mouse diaphragm are innervated (Lin et al., 2001).

An alternate hypothesis to explain the aberrant neuronal branching is that MyoD might be required, directly or indirectly, to downregulate the expression of growth-promoting signaling factors present in the extrasynaptic regions of developing muscle before innervation. Failure of the MyoD-deficient muscles to repress their expression could encourage axons to grow over the entire surface of the muscle.

We demonstrate that key events in the agrin-MuSK-rapsyn signaling cascade are unimpaired in MyoD-deficient myotubes. First, neural agrin induces the same number of clusters per unit area of myotube in cultures derived from $\mathrm{MyoD}^{-/-}$and BALB/c muscles. Second, nerve-independent (but rapsyn and MuSK dependent) (Yang et al., 2001) clustering of AChR in both types of muscles occurs by E14.5. Third, the nerves that grow toward the periphery of the mutant diaphragm release agrin and induce AChR clusters at sites distal to the normal endplate zone. Fourth, numbers of endplates on the hemi-diaphragm of adult $\mathrm{MyoD}^{-/-}$ and BALB/c mice are similar. Fifth, muscle fibers in $M y o D^{-/-}$ mice assemble a complex postsynaptic apparatus that includes MuSK, rapsyn, erbB, and utrophin. Aberrant growth of motor axons has been described in muscles of mice lacking rapsyn or
MuSK (Gautam et al., 1995; DeChiara et al., 1996); however, the pattern of intramuscular nerve branching in these mutants is different, and these mice fail to cluster synaptic proteins (Gautam et al., 1995; DeChiara et al., 1996).

\section{MyoD and postsynaptic differentiation} at the neuromuscular junction

AChR clusters appear as oval plaques, and the density of junctional folds is reduced at the endplates of adult $M y o D^{-/-}$mice. This occurs despite the fact that the size of the motor neuron pool innervating the diaphragm muscle of the mutant mouse is similar to that innervating wild-type muscle. Although the cause of these changes has not been determined definitively, the AChR $\gamma$ - to $\epsilon$-subunit transition in wildtype muscle coincides with the formation of junctional folds. Because the transition to adult AChRs is delayed considerably in $M y o D^{-/-}$mice, changes in synaptic ultrastructure might result from the lack of the $\epsilon$-subunit during early postnatal development. A similar reduction in the density of junctional folds has been described in mice in which the $\epsilon$-subunit of the AChR is missing. Differences in protein sequences of the $\gamma$-and $\epsilon$-subunits may cause them to interact differently with components of the cytoskeleton or extracellular matrix, altering recruitment of some synaptic components. Alternatively, differences in the postsynaptic current generated by two types of channels could affect the maturation of postsynaptic specializations (Missias et al., 1997).

\section{MyoD and the switch from the fetal to adult AChRs}

Although it is suggested above that alterations in the postsynaptic folds in the $M y o D^{-/-}$endplates are the result of the delay in appearance of the adult AChR, the converse should also be considered (i.e., the reduction of synaptic folds may result in a transmission failure, which could result in the delay in the maturation of the AChRs). However, that the time of elimination of polyneuronal innervation is similar in $\mathrm{BALB} / \mathrm{c}$ and $\mathrm{MyoD}^{-/-}$muscles suggests that transmission is adequate during the early postnatal period. Alternately, the lack of MyoD could directly or indirectly affect AChR subunit transcription.

In view of the facts that (1) two E boxes are necessary for full transcriptional activity of the $\gamma$-subunit gene (Durr et al., 1994), (2) MyoD can transactivate reporter genes under the control of the $\gamma$-subunit promoter in vitro (Jia et al., 1992), and (3) MyoD protein can bind to $\mathrm{E}$ boxes of the $\gamma$-subunit gene in the $\mathrm{C}_{2} \mathrm{C}_{12}$ myoblasts (Liu et al., 2000), it was unexpected that the absence of MyoD would prolong the expression of the $\gamma$-subunit gene. However, myf-5 (increased 3.5-fold in the $M y o D^{-/-}$muscles) (Rudnicki et al., 1992) is more efficient than MyoD in the transactivation of the $\gamma$-subunit gene (Durr et al., 1994). This could explain the continued transcription of the $\gamma$-subunit gene in $M y o D^{-/-}$muscle at a time when it is absent in wild-type muscle.

Detection of substantial levels of the $\epsilon$-subunit was delayed in $\mathrm{MyoD}^{-/-}$muscles until P21. This, too, was not anticipated because 
expression of the $\epsilon$-subunit gene is induced in synaptic nuclei by a motoneuron-derived factor, neuregulin (Sandrock et al., 1997). Binding of neuregulin to erbB receptors leads to the activation of an Ets-related transcription factor, GA-binding protein (GABP), which binds to N-box sequences in the promoter of the $\epsilon$-subunit, enhancing the transcription of that gene (Schaeffer et al., 1998).

What role does MyoD play? Although the $\epsilon$-subunit promoter reportedly can be partially independent of the MRFs (Duclert et al., 1993), the MRFs (including MyoD) efficiently transactivate the $\epsilon$-promoter (Sunyer and Merlie, 1993). Recently, Liu et al. (2000) demonstrated that all four MRFs bind to the $\epsilon$-subunit promoter in proportion to their relative level in $\mathrm{C}_{2} \mathrm{C}_{12}$ myotubes. If this phenomenon holds in vivo, then during the switch to the adult receptors, MyoD may play a role in the transcription of the $\epsilon$-subunit gene, because during the first week postnatal, MyoD mRNA is the second most abundant of the four MRF transcripts in wild-type muscles (C. H. Washabaugh, unpublished data).

An alternate explanation for the delayed appearance of the $\epsilon$-subunit in the $M y o D^{-1-}$ muscles is suggested from a hypothesis, proposed by Schaeffer et al. (1998), that GABP may interact with the MRFs. Interaction is possible on the basis of the following: (1) the proximity of the $\mathrm{N}$ box and $\mathrm{E}$ box in the $\epsilon$-promoter; (2) Ets factors often function in cooperation with other transcription factors. GABP can form a bHLH-like motif, promoting interactions with members of the bHLH family (Schaeffer et al., 1998). In the absence of MyoD, these interactions may be reduced significantly.

The formation of migratory muscles, including the limb, diaphragm, and intercostal muscles, is delayed by $\sim 2.5 \mathrm{~d}$ in the $\mathrm{MyoD}^{-/-}$mouse (Kablar et al., 1997, 1998); however, preliminary electron microscopy studies indicate that there is no difference in diaphragm muscle maturation in the $\mathrm{MyoD}^{-1-}$ versus the wild-type control mice. Surprisingly, muscles taken from E14, E16, and E18 wild-type and $M y o D^{-/-}$mice are indistinguishable on the basis of morphological criteria (extent of myofibril assembly, time course of formation of secondary myotubes, time of migration of myonuclei from their central to their peripheral positions) (Ontell, unpublished observations). That the transition from $\gamma$ - to $\epsilon$-AChR in $M y o D^{-/-}$mouse is delayed by 2 weeks and that muscle formation is delayed by $\sim 2.5 \mathrm{~d}$ suggests that the delay in AChR maturation is not related to the delay in muscle formation. Moreover, that AChR clusters are present in both wild-type and $\mathrm{MyoD}^{-1-}$ diaphragms at E14.5, that the nerve has induced new AChRs by E15.5, that by this stage $>90 \%$ of the AChR clusters in both types of muscle are innervated, and that polyneuronal innervation is eliminated by $\mathrm{P} 14$ in $\mathrm{MyoD}^{-/-}$and $\mathrm{BALB} / \mathrm{c}$ diaphragms suggest that the time course of neuromuscular integration is not affected in the $\mathrm{MyoD}^{-/-}$mice.

In conclusion, the present study provides evidence that MyoD is involved in mechanisms modulating neuromuscular integration during development. In the absence of this muscle-specific
$\mathrm{BALB} / \mathrm{c}$
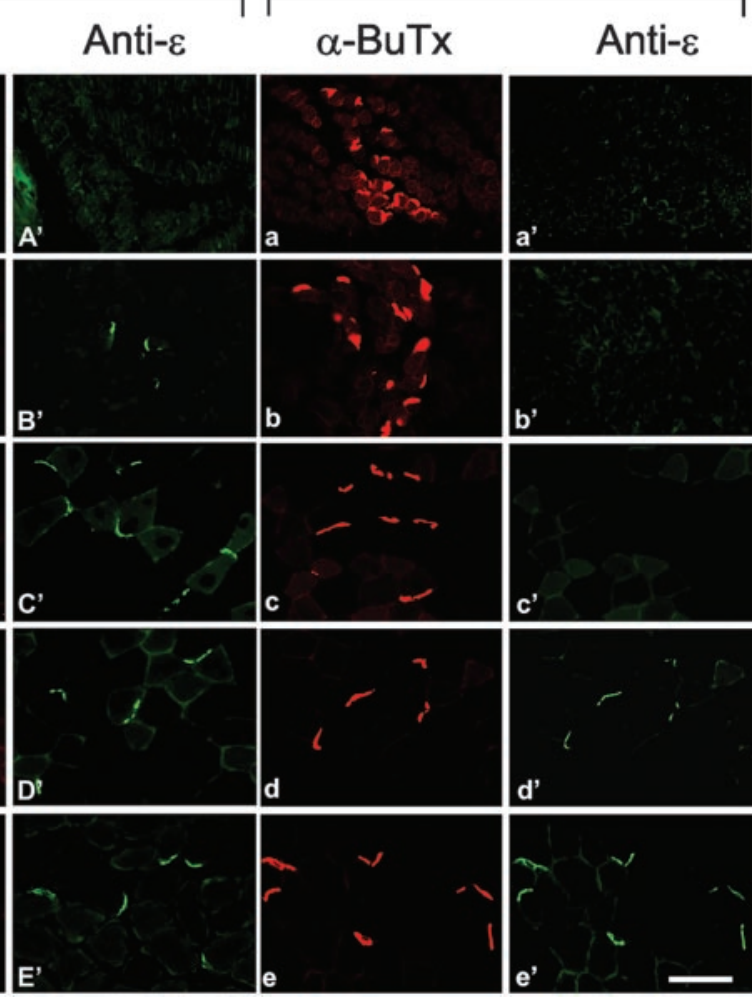
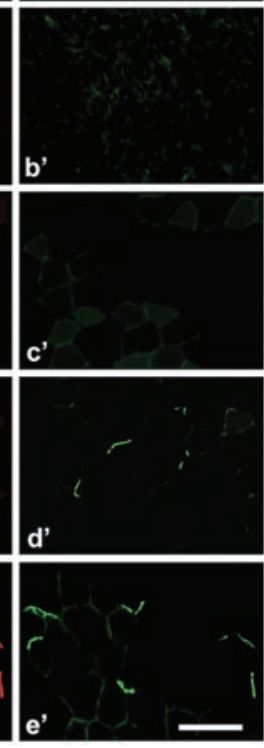

Anti- $\varepsilon$
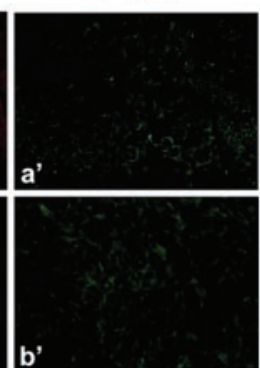

Figure 6. Delayed expression of the $A C h R \epsilon$-subunit in leg muscles of the $M y 0 D^{-/-}$mice. Confocal images of sections of the tibialis anterior muscle, taken from P1-P28 BALB/c (left panels) and $\mathrm{MyOD}^{-/-}$(right panels) mice, that were incubated with an antibody to the $\epsilon$-subunit, FITC-conjugated secondary antibody, and rhodamine-labeled $\alpha$-BuTx. The $\epsilon$-subunit is clearly visible by $\mathrm{P} 7$ in the $\mathrm{BALB} / \mathrm{c}$ mice, whereas the $\epsilon$-subunit in $\mathrm{MyoD}^{-1-}$ mice is clearly visible by P21. Scale bar, $50 \mu \mathrm{m}$.

transcription factor, the pattern and extent of axonal branching in the mouse diaphragm are altered, the distribution of endplates is diffuse, rather than confined to a discrete endplate band, the complexity of postsynaptic folds is reduced, and the time course of the switch from the fetal to the adult AChR is delayed.

\section{References}

Allen DL, Sartorius CA, Sycuro LK, Leinwand LA (2001) Different pathways regulate expression of the skeletal myosin heavy chain genes. J Biol Chem 276:43524-43533.

Apel ED, Roberds SL, Campbell KP, Merlie JP (1995) Rapsyn may function as a link between the acetylcholine receptor and the agrin-binding dystrophin-associated glycoprotein complex. Neuron 15:115-126.

Brennan TJ, Edmondson DG, Olson EN (1990) Aberrant regulation of MyoD1 contributes to the partially defective myogenic phenotype of BC3H1 cells. J Cell Biol 110:929-937.

Buckingham ME (1994) Muscle: the regulation of myogenesis. Curr Opin Genet Dev 4:745-751.

Buonanno A, Apone L, Morasso MI, Beers R, Brenner HR, Eftimie R (1992) The MyoD family of myogenic factors is regulated by electrical activity: isolation and characterization of a mouse Myf-5 cDNA. Nucleic Acids Res 20:539-544.

Campagna JA, Ruegg MA, Bixby JL (1995) Agrin is a differentiationinducing "stop signal" for motoneurons in vitro. Neuron 15:1365-1374.

Cifuentes-Diaz C, Goudou D, Padilla F, Facchinetti P, Nicolet M, Mege R-M, Rieger F (1996) M-cadherin distribution in the mouse adult neuromuscular system suggests a role in muscle innervation. Eur J Neurosci 8:1666-1676.

Cifuentes-Diaz C, Faille L, Goudou D, Schachner M, Rieger F, Angaut-Petit D (2002) Abnormal reinnervation of skeletal muscle in a tenascin-Cdeficient mouse. J Neurosci Res 67:93-99.

Cornelison DDW, Olwin BB, Rudnicki MA, Wold BJ (2000) $\mathrm{MyoD}^{-1-}$ satellite cells in single fiber culture are differentiation defective and MRF4 deficient. Dev Biol 224:122-137. 
Davis RL, Weintraub H, Lassar AB (1987) Expression of a single transfected cDNA converts fibroblasts to myoblasts. Cell 51:987-1000.

DeChiara TM, Bowen DC, Valenzuela DM, Simmons MV, Poueymirou WT, Thomas S, Kinetz E, Compton DL, Rojas E, Park JS, Smith C, DiStefano PS, Glass DJ, Burden SJ, Yancopoulos GD (1996) The receptor tyrosine kinase MuSK is required for neuromuscular junction formation in vivo. Cell 85:501-512.

Duclert A, Savatier N, Changeux JP (1993) An 83 nucleotide promoter of the acetylcholine receptor epsilon-subunit gene confers preferential synaptic expression in mouse muscle. Proc Natl Acad Sci USA 90:3043-3047.

Durr I, Numberger M, Berberich C, Witzemann V (1994) Characterization of the functional role of E-box elements for the transcriptional activity of rat AChR epsilon-subunit and gamma-subunit gene promoters in primary muscle cell cultures. Eur J Biochem 224:353-364.

Eftimie R, Brenner HR, Buonanno A (1991) Myogenin and MyoD join a family of skeletal muscle genes regulated by electrical activity. Proc Natl Acad Sci USA 88:1349-1353.

Ferns MJ, Campanelli JT, Hoch W, Scheller RH, Hall Z (1993) The ability of agrin to cluster AChRs depends on alternative splicing and on cell surface proteoglycans. Neuron 11:491-502.

Fuhrer C, Sugiyama JE, Taylor RG, Hall ZW (1997) Association of musclespecific kinase MuSK with the acetylcholine receptor in mammalian muscle. EMBO J 16:4951-4960.

Gautam M, Noakes PG, Mudd J, Nichol M, Chu GC, Sanes JR, Merlie JP (1995) Failure of postsynaptic specialization to develop at neuromuscular junctions of rapsyn-deficient mice. Nature 377:232-236.

Gautam M, Noakes PG, Moscoso L, Rupp F, Scheller RH, Merlie JP, Sanes JR (1996) Defective neuromuscular synaptogenesis in agrin-deficient mutant mice. Cell 85:525-535.

Gilmour BP, Fanger GR, Newton C, Evans SM, Gardner PD (1991) Multiple binding sites for myogenic regulatory factors are required for expression of the AChR gamma-subunit gene. J Biol Chem 266:19871-19874.

Grady RM, Zhou H, Cunningham JM, Henry MD, Campbell KP, Sanes JR (2000) Maturation of the neuromuscular synapse: genetic evidence for the roles of the dystrophin-glycoprotein complex. Neuron 25:279-293.

Gu Y, Hall ZW (1988) Immunological evidence for a change in subunits of the AChR in developing and denervated rat muscle. Neuron 1:117-125.

Gullick WJ, Lindstrom JM (1983) Mapping the binding of monoclonal antibodies to the acetylcholine receptor from Torpedo californica. Biochemistry 22:3312-3320.

Jia HT, Tsay HJ, Schmidt J (1992) Analysis of binding and activating functions of the chick muscle AChR gamma-subunit upstream sequence. Cell Mol Neurobiol 12:241-258.

Kablar B, Krastel K, Ying C, Asakura A, Tapscott SJ, Rudnicki MA (1997) MyoD and myf-5 differentially regulate the development of limb versus trunk skeletal muscle. Development 124:4729-4739.

Kablar B, Asakura A, Krastel K, Ying C, May LL, Goldhammer DJ, Rudnicki MA (1998) MyoD and myf-5 define the specification of musculature of distinct embryonic origin. Biochem Cell Biol 76:1079-1091.

Karnovsky MJ, Roots L (1964) A "direct-coloring" thiocholine method for cholinesterase. J Histochem Cytochem 12:219-221.

Kaufmann U, Martin B, Link D, Witt K, Zeitler R, Reinhard S, StarzinskiPowitz A (1999) M-cadherin and its sisters in development of striated muscle. Cell Tissue Res 296:191-198.

Landmesser L (1996) Cell adhesion/recognition molecule-mediated steps during the guidance of commissural and motor axons. Prog Brain Res 108:109-116.

Lin W, Burgess RW, Dominguez B, Pfaff SL, Sanes JR, Lee KF (2001) Distinct roles of nerve and muscle in postsynaptic differentiation of the neuromuscular synapse. Nature 410:1057-1064.

Liu S, Spinner DS, Schmidt MM, Danielsson JA, Wang S, Schmidt J (2000) Interaction of MyoD family proteins with enhancers of $\mathrm{AChR}$ subunit genes in vivo. J Biol Chem 275:41364-41368.

Megeney LA, Kablar K, Garrett K, Anderson JE, Rudnicki MA (1996) MyoD is required for myogenic stem cell function in adult skeletal muscle. Genes Dev 10:1173-1183.

Merlie JP, Sanes JR (1985) Concentration of AChR mRNA in synaptic regions of adult muscle fibres. Nature 317:66-68.

Missias AC, Mudd J, Cunningham JM, Steinbach JH, Merlie JP, Sanes JR (1997) Deficient development and maintenance of postsynaptic special- izations in mutant mice lacking an "adult" acetylcholine receptor subunit. Development 124:5075-5086.

Moscoso LM, Cremer H, Sanes JR (1998) Organization and reorganization of neuromuscular junctions in mice lacking neural cell adhesion molecule, tenascin-C, or fibroblast growth factor-5. J Neurosci 18:1465-1477.

Numberger M, Durr I, Kues W, Koenen M, Witzemann V (1991) Different mechanisms regulate muscle-specific AChR gamma- and epsilon-subunit gene expression. EMBO J 10:2957-2964.

Ontell M, Bourke D, Hughes D (1988) Cytoarchitecture of the fetal murine soleus muscle. Am J Anat 181:267-278.

Ontell MP, Hughes D, Hauschka SD, Ontell M (1992) Transient neonatal denervation alters the proliferative capacity of myosatellite cells in dystrophic (129ReJdy/dy) muscle. J Neurobiol 23:407-419.

Piette J, Bessereau JL, Huchet M, Changeux JP (1990) Two adjacent MyoD1-binding sites regulate expression of the AChR alpha-subunit gene. Nature 345:353-355.

Prody CA, Merlie JP (1991) A developmental and tissue-specific enhancer in the mouse skeletal muscle AChR alpha-subunit gene regulated by myogenic factors. J Biol Chem 266:22588-22596.

Rimer M, Cohen I, Lomo T, Burden SJ, McMahan UJ (1998) Neuregulins and erbB receptors at neuromuscular junctions and at agrin-induced postsynaptic-like apparatus in skeletal muscle. Mol Cell Neurosci 12:1-15.

Rosenthal N, Berglund EB, Wentworth BM, Donoghue M, Winter B, Bober E, Braun T, Arnold HH (1990) A highly conserved enhancer downstream of the human MLC1/3 locus is a target for multiple myogenic determining factors. Nucleic Acids Res 18:6239-6246.

Rudnicki MA, Braun T, Hinuma S, Jaenisch R (1992) Inactivation of MyoD in mice leads to up-regulation of the myogenic HLH gene Myf-5 and results in apparently normal muscle development. Cell 71:383-390.

Sabourin LA, Rudnicki MA (2000) The molecular regulation of myogenesis. Clin Genet 57:16-25.

Sabourin LA, Girgis-Gabardo A, Seale P, Asakura A, Rudnicki MA (1999) Reduced differentiation potential of primary $\mathrm{MyoD}^{-1-}$ myogenic cells derived from adult skeletal muscle. J Cell Biol 144:631-643.

Sandrock Jr AW, Dryer SE, Rosen KM, Gozani SN, Kramer R, Theill LE, Fischbach GD (1997) Maintenance of AChR number by neuregulins at the neuromuscular junction in vivo. Science 276:599-603.

Sanes JR, Lichtman JW (2001) Induction, assembly, maturation and maintenance of a postsynaptic apparatus. Nat Rev Neurosci 2:791-805.

Schaeffer L, Duclert N, Huchet-Dymanus M, Changeux JP (1998) Implication of a multisubunit Ets-related transcription factor in synaptic expression of the nicotinic acetylcholine receptor. EMBO J 17:3078-3090.

Schaeffer L, de Kerchove d'Exaerde A, Changeux JP (2001) Targeting transcription to the neuromuscular synapse. Neuron 31:15-22.

Seward D, Haney J, Rudnicki M, Swoap S (2001) bHLH transcription factor MyoD affects myosin heavy chain expression pattern in a muscle-specific fashion. Am J Physiol Cell Physiol 85:C408-C413.

Simon AM, Burden SJ (1993) An E box mediates activation and repression of the AChR delta-subunit gene during myogenesis. Mol Cell Biol 13:5133-5140.

Sunyer T, Merlie JP (1993) Cell type and differentiation-dependent expression from the mouse acetylcholine receptor epsilon-subunit promoter. J Neurosci Res 36:224-234.

Thieler K (1989) The house mouse. Berlin: Springer.

Voytik SL, Przyborski M, Badylak SF, Konieczny SF (1993) Differential expression of muscle regulatory factor genes in normal and denervated adult rat hindlimb muscles. Dev Dyn 198:214-224.

Washabaugh CH, Ontell MP, Kant JA, Daood MJ, Watchko JF, Watkins SC, Ontell M (2001) Effect of chronic denervation and denervationreinnervation on cytoplasmic creatine kinase trancript accumulation. J Neurobiol 47:194-206.

White JD, Scaffidi A, Davies M, McGeachie J, Rudnicki MA, Grounds MD (2000) Myotube formation is delayed but not prevented in MyoDdeficient skeletal muscle: studies in regenerating whole muscle grafts of adult mice. J Histochem Cytochem 48:1531-1544.

Yang X, Li W, Prescott ED, Burden SJ, Wang JC (2000) DNA topoisomerase II $\beta$ and neural development. Science 287:131-134.

Yang X, Arber S, William C, Li L, Tanabe Y, Jessell TM, Birchmeier C, Burden SJ (2001) Patterning of muscle acetylcholine receptor gene expression in the absence of motor innervation. Neuron 30:399-410. 